\title{
Effect of Corporate Reputation and Commitment of Business Social Responsibility (BSR) on Performance: Evidence from Manufacturing Sector in Nigeria
}

\author{
Abdullahi Hassan Gorondutse \\ School of Business Management, College of Business \\ Universiti Utara Malaysia
}

\section{Doi:10.5901/mjss.2013.v4n7p21}

\begin{abstract}
The concern of business social responsibility calls and perceptive among scholars and practitioners has led to postulation that social activities would lead to competitive advantages. This paper examine tactical values in developing nation particularly Nigeria, and how it's related to performances of manufacturing sector. Using a survey data of 248 usable questionnaires, the data were analysed using SEM. However, the result reveals positive association between corporate reputation and organizational performance. Surprisingly, BSR commitment was insignificant to organizational performance. This indicate that despite awareness and understanding of business social responsibility by manufacturing sector in Nigeria, but still concern of social behaviour may be lacking, in terms of commitment to social issues. Managerial implication and direction of future studies were also discussed.
\end{abstract}

Keywords: Corporate reputation, commitment to BSR, organizational performance and Nigeria.

\section{Introduction}

For many years a vast body of knowledge has emerged concerning the association between initiatives and organizational performance (Peloza \& Papania, 2008). Despite all this attempt of research it suffers with major limitations. This paper seek to address one of the limitation, previous research on this connection between BSR on organizational performance were mainly focused in USA and Europe. To date few scholar have investigate the strategies policy of BSR in developing nation even if any they highly concentrated on multinational corporation (Amaeshi, Adi, Ogbechie \& Amao, 2006; frynas, 2005, Okeye, 2009; Perdeson \& Hunnache, 2006).

In this paper we aim to close this paucity by focusing BSR commitment and corporate reputation in emerging nation. Data collected from manufacturing industry operating in Nigeria. Despite the fact that business in developing nations have different system from those in USA and Europe. This information is very significant because organization need to recognized the important of business ethics and social responsibility dimension in their decision making process before they can apply then in business setting (Hsu, 2012; Retab, Brik, \& Mellahi, 2009).

The perspective of BSR actions entail the dependence of business success on the relation and interactions between an organization and its stakeholder for example, in ability of the business to satisfy its customers need or want to make available suitable pricing pair safe, hygienic products. Also as component of international strategies business threat losing regular direct if they fail to meet the environmental regulation required by its consumers. Therefore, business must enhance their corporate reputation to meet the changing demands of the diverse stakeholder.

However, previous studies have empirically identified the associations between BSR and corporate reputation (Lai, Chiu, Yang, \& Pai, 2010; Retab et al., 2009). But the way in which BSR initiative influences 
these outcomes remains uncertain. Consequently, a number of researches have argued that the lack of agreement on the relationship between BSR dimension and organizational performances (Hillman \& Keim, 2001; Peloza \& Papania, 2008; Retab et al., 2009; Waddock \& Graves, 1997; Wright \& Ferris, 1997), and this points the need for further studies into this relation particularly in developing nation where there are little empirical evidence. In addition, the research is significant; firstly, there is large inequality in the number of studies on social responsibility especially in small firms (local firms). To date research on BSR are highly concentrated on larger firms (Ahmad \& Ramayah, 2012; Egri, \& Rosland, 2008; Lee, 2008; Morris, Schindehutte, Walton, \& Allen, 2002). Secondly, while there is increasing awareness about BSR in emerging nation still most of the research has been examined in developed economics.

The main objective of this paper is to examine the relationship between BSR commitment and corporate reputation on organizational performance, to the best of our knowledge no related research exist in the context of the study. The paper is organized as follow, the reminder section review previous research on BSR, Commitment and corporate reputation to developed a conceptual framework that indicates the significant relationship between these variables, next we tested the predicted path ways in the framework, finally the paper discuss the managerial and theoretical implication of the study.

\section{Literature review}

\subsection{Business social responsibility}

Basically business social responsibility is a displeased and contentious issue; According to smith (2003) BSR refers to the obligation of business to community those who are affected by its corporate strategies and practices. On the other hand Wright (2006) define socially responsible practices as the positive activities a business undertakes in the society in which it operates and this includes responsibility towards customers, employees, and the public. The existing approaches to BSR are split (Porter \& Kramer, 2006), but three essential lines of BSR are: Stakeholder - driven, Performance - driven, and Motivation - driven approaches (Basu \& Palazzo, 2008). The first, which is stakeholder - driven in this approach business manager try to gather the need and want of stockholder and external holder, the action of BSR is a response to the demands of stakeholder about general social concerns or the business operation. Lack of BSR practices and actions these group of stakeholder might withdraw their support from business (Freeman, 1984; Maignan, Ferrell, \& Ferrell, 2005; McWillian, Siegel, \& Wright, 2006).

The next approach is the performance- driven which is concerns the association among BSR, corporate strategy and essential performance. This lead the researchers to centre on influential actions to implement BSR and then measuring their effectiveness, BSR actions include incorporating social concern into products, adopting progressive human resources management practices, centre on environmental performance and advancing the goals of community organization (Maignan, et al., 2005; McWillian et al., 2006). And the last approach is the motivation- driven approach which examines the extrinsic reasons for a firms BSR commitment or the intrinsic rationales to advance notions of its conscientiousness and responsibilities (Basu and Palazzo, 2008). The extrinsic reason concern flattering outcomes toward focal business, for example enhancing reputation (Fombrum, 2005) consumer's resilience to negative information (Bhattacharya \& Sen, 2004) and Managing risk (Husted, 2005). On the other hand the intrinsic rationale draws on philosophic concepts, such as contract theory, Aristolian \& Kantian ethical concepts (Basu \& Palazzo, 2008).

However, each of this approach mentioned above, lead to unique interpretation of BSR, for instance, the stakeholder- driven explain and measure BSR, the performance-driven define activities and lastly, the motivation-driven reveals penalty, hence, this study will be guided by the stakeholder-driven approach. 


\subsection{Corporate reputation}

Business managers believe corporate reputation is the critical elusive resource that leads to competition advantage (Siltaoja, 2006). The significant of corporate reputation has been supported by a highly positive connection between corporate reputations and its return of assets (Deephouse, 2000; Roberts \& Dowling, 2002). There are numerous of enabling machinery support to this procedure, a good reputation insulates the business from stakeholder perception of negative information (Lange, Lee \& Dai, 2011). In addition a significant reputation is also attractive to employee and customer (Lange et al., 2011).

Similarly, the association between corporate reputation and BSR in developing economics like Nigeria is not uncomplicated. The impact of BSR on corporate reputation in the eyes of diverse but mostly external stakeholder is twisted by how the business converse its BSR actions and how its activities are reported in the national media and other communication media. A business can use BSR deeds as machinery to indicator desirability features to stakeholder (Fombrun, 2005). BSR can be viewed as a form of strategic investment in reputation building or maintenance by making strategic investment in reputation.

\subsection{BSR Commitment}

Commitment has got considerable interest in research, due to its important impact on job attitudes such as presentation, non-attendance, and turnover intentions (Ahmad, Veerapandian \& Ghee, 2011; Lokand \& Crawford, 2001; Rangriz \& Mehrabi, 2010). Porter Steers, Moeday, and Boulian, (1974) has provide with the three-parts of organisational commitment definition: A well-built principle in and recognition of the organisation's aims and standards, a readiness to exercise substantial endeavour on behalf of the organisation, and a strong wish to stay in the administration. Allen and Meyer (1990) conceptualized a form of organisational commitment and classified three parts: affective, continuance, and normative commitment. However, Steers (1977), Chew \& Chan, (2006) found that commitment was generally unconnected to performance (weak relationship). This is due to numerous variables. First, it was reveals that the sample sizes (two organizations) in the study had difficulties in irritating to decrease revenue rate and nonattendance. The business managers also be likely to keep more conscious "settlers" and trustworthy, but to whom better performance was not role significant. The business also finished up being steadier, but less productive or inventive labor force. The managers in both organizations were powerfully disturbed about worker retentions rather than about greater performance.

The result of the above is inconsistent with Miller and Lee (1999) who establish that organizational commitment was absolutely related to the financial performance. This means that organizational commitment could have an effect on the organizational performance. Considering the previous studies, it seems to be that there is a linked concerning firm's commitment and organizational performance. Therefore, each of these associations had been used as independent factors. Other studies have investigate only the affective component of organisational commitment (Ambrose, Arnaud, \& Schminke, 2008; Chew \& Chan, 2006; Rashid et al., 2003), or all the three parts as well as the total organisational commitment (Ahmad et al., 2011; Huang, Cheng \& Chow, 2005). On the other hand, this study has selected this advance, and uses organisational commitment as a uni- construct, and this approach has been adapted in this study for the same reason.

\subsection{BSR and Organizational Performance}

Previous research on the relationship between BSR and organizational performance found a numerous finding some reveals that positive, others negative and mixed or non-significant relation, those who reveals the positive relation includes (Griffin \& Mahon, 1997; Peloza \& Papania, 2008; Porter \& Vander linde, 1995; Preston \& V' Bannon, 1997; Rettab, Brik \& Mellahi, 2009 \& Verschoor, 1998) while those indicate negative 
includes (Meznar et al., 1994; Vance, 1975 \& Wright \& Ferris, 1997) and lastly, those who indicate mixed result include ( Berman et al., 1999; Cochran \& Wood, 1984; Graves \& Waddock, 1997; Hillman \& Kein, 2001 \& McGuire, Sundegren, \& Schneeweis, 1988). However, as noted earlier we cannot generalize the above finding because all the result comes from USA and Europe as against the developing nation. In line with this Business system theory (Whitley, 1992) state that countries have diverse business systems. This gives ample evidence that in order to assume a relationship between BSR and organizational performance in developing nation particularly Nigeria, one has to consider Commitment and corporate reputation on social issues business has on its numerous stakeholders.

\subsection{BSR and Corporate Reputation}

Previous research to date provides and evidence that corporate reputation is a fundamental subtle resources that give a firms reasonable benefit (Brammer \& Millington, 2005; Fombrun \& Shanley, 1990; Hsu, 2012; Lai et al., 2010; Shamsie, 2003; Retab et al., 2009). Although the connection between BSR and corporate reputation in developing nation are not clear-cut this is because businesses functioning in emerging nation are lacking skills and tradition in communicating internal actions such as BSR activities. This limits the business ability to influence stakeholder perception in order to boost its corporate reputation. Hsu (2012), Lai et al., (2010) reveals the association between BSR and brand performance is partially mediated by corporate reputation. This means that consumer perception about firms BSR initiatives positively related to corporate reputation. Therefore, we posit:

$\mathrm{H1}$ : Corporate reputation is positively related to Organizational performances.

\subsection{BSR Commitment and Organizational performances}

The relationship between organisation commitment and performances has been documented by the previous studies, considering the dimension of organisational commitment (affective, continuous and normative). For example Organizational commitment is fundamental within individual and organizational performance studies (Swailes, 2002), with applications to marketing (Jaworski \& Kohli, 1993). The literature presents many definitions of the theoretical concept (Swailes, 2002,) including both employee donations and a sense of togetherness to the organization (Jaworski \& Kohli, 1993).

Consequently, Aguilera, Ruth, Rupp, Williams \& Ganapathi (2007) emphasis that commitment make judgment about their firms BSR efforts based on their observation of the firms BSR practices, outcomes of the BSR actions and the managing of the execution process. The author asserts that socially responsible or irresponsible actions are serious consequence to organization. A numerous of studies have explored the connection between commitment and organizational performance (Ahmad, Veerapandian \& Ghee 2011; Chew \& Chan, 2006; Huang, Cheng \& Chow, 2005; Rashid, Sambasivan, \& Johari, 2003). Above all past research shows that firms commitment to BSR issues action tend to have a positive impact on performances.

In addition, contrary to presumed connection between BSR actions and drivers of financial performance, given that a number of business in developing nations take advantages of weak commitment to social issues. Taking the above arguments as whole, we posit:

$\mathrm{H} 2$ : BSR commitment is positively related to organizational performances in developing nation. 
Figure 1. Research framework

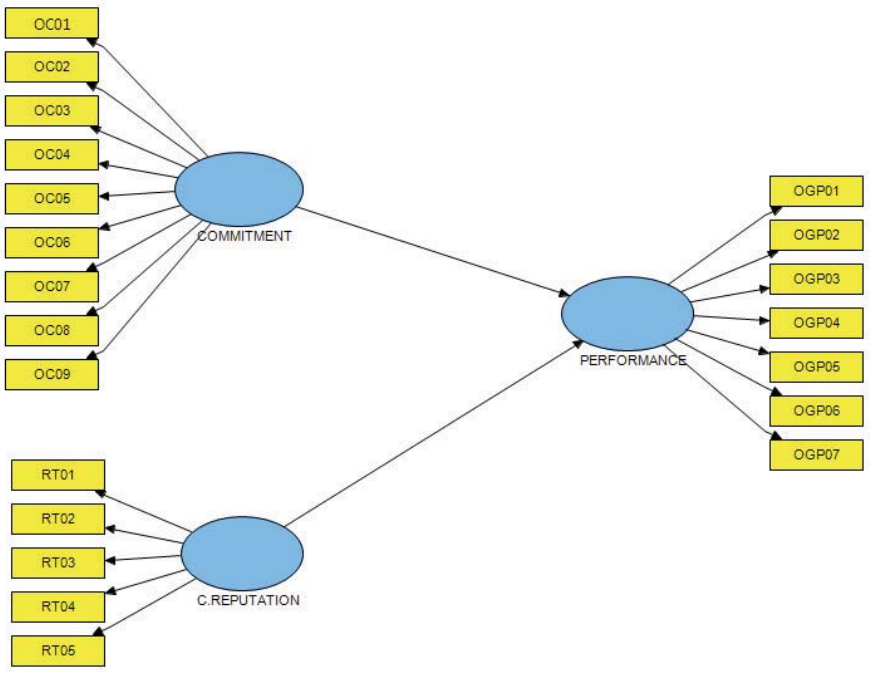

\section{Methodology}

\subsection{Sample and Data Collection}

The population of this study consist of 1500 manufacturing sector register with SMEDAN as at 2010 in Kano state North-West of Nigeria. This because the state is the centre of commerce and virtually all manufacturing industry in Nigeria has one or more factory in the state (Sani \& Suleiman, n.d), Additionally, the city and nature of commercial activities attract people of different religions and ethnic background. Hence, to this extent, it could be said the sample that will be derived from this population will be relatively homogeneous. The study employs a simple random sampling technique, in concurrence with sample selection formulae, which is stated as follows, Yemane (1967).

$$
\mathrm{n}=\frac{N}{1+N(e)^{2}}
$$

Where: $\mathrm{n}=$ Sample size; $\mathrm{N}=$ Population of the study; $\mathrm{e}=$ Level of precision.

$$
\begin{aligned}
& n=\frac{1500}{1+1500(0.05)^{2}} \\
& n=\frac{1500}{1+1500(0.0025)} \\
& n=\frac{1500}{1+3.75} \\
& n=\frac{1500}{4.75} \\
& n=316 .
\end{aligned}
$$

Therefore, base on the above formulae a representative of sample size of three hundred and sixteen (316) was selected from the population of 1500 manufacturing industry in the state with precision level of $\pm 5 \%$ and the level of confidence is $95 \%$. Consequently, out of 316 hundred copies of questionnaire distributed, a total of two hundred and sixty one copies of questionnaires were returned completed, representing $82.6 \%$ percent response rate which is superb. 8 copies of questionnaire were discarded due to number of missing data. Before testing, variables were examined through various SPSS version 18 
measures for a better precision of data entry, missing value, and fit between distributions and the assumptions of structural equation modelling. 5 cases were identified through the process of mahalanobis distance analysis, as multivariate outliers with a $P$ value $<0.05$. These respondents were automatically deleted. Leaving 248 cases for analysis.

\subsection{Measurement}

\subsubsection{Corporate reputation}

Corporate reputation is joint representations of business long-ago activities and potential prospects that explain how key resource providers interpret a business initiatives and assess its ability to deliver valued customers (Petrick, 2002). Dodds, Monroe \& Grewal (1991) refer it as the prestige or status of a product or service as perceived by the purchaser based on the image of the supplier. Similarly Lai, Chiu, Yang \& Pai (2010) sees corporate reputation as the general intuition dazzling the perception of a combined stakeholder group. Therefore, in the present study we refer corporate reputation as the general impression reflecting the key stakeholder perception about the business initiatives particularly on the social responsibility issue and the assessments about the business product or services. Five items were adapted from Petrick (2002) to measure the construct, and was tested by Hsu (2012) and to achieve internal consistence reliability and convergent validity.

\subsubsection{BSR Commitment}

Organisational commitment was measured using Allen and Meyer"s (1990) this scale is commonly used in social sciences and has excellent psychometric properties in cross-cultural research (Schmidt, 2007). For the reason of this research organisational commitment will be treated as single as earlier mention and measure by nine items out of the fifteen items from (Mowday, Porter \& Steers, 1982). The items will be selected on the foundation of having the most face validity in the opinion of the researcher (Ahmad et al.,2011; Huang et al., 2005). The sample items will be adapt and modified in order to suit the study. The following items will be use to measure organizational commitment my organization is willing to put effort normally expected on the issue of BSR. This questionnaire requires organization to indicate their level of agreement with the extent to which they are identified with and involved in their organization. The responses of all items in the questionnaire were made on a 7-point scale ranging from 1 strongly disagree to 7 strongly agree.

\subsubsection{Organizational Commitment}

Organizational performance, or firm performance as we refer to it in this study, is a division of organizational efficiency that covers operational and financial outcomes (Cameron, 1986), This can be characterized into two main groups which are financial performance and non-financial performance. Financial performance is, for example, profitability, liquidity and financial risk, which are earnings, associated to enterprises' efficiency per operation. Non financial performance is usually associated with customer base, brand devotion, image and reputation, technology and initiatives development as well as quality of human resources (Kaplan \& Norton, 2000). For this reason, the study will adapt this scale because over the years many researchers have suggested that performance measurement should includes both financial and non- financial measurement investigation which is measure by 7 items ( Kaplan \& Norton , 1992; Venkantrannan \& Ramanujan, 1986). 
Figure 1. Revised Model

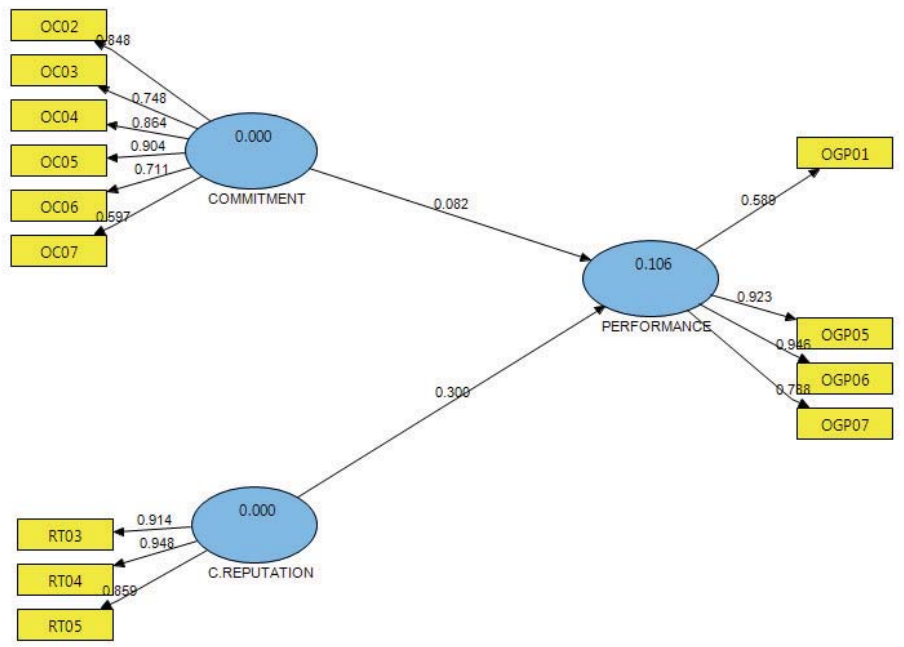

\subsection{Analysis Method}

Data were analyzed using Structural Equation Modeling (SEM), through Partial Least Square (SmartPLS 2) due to the fact that PLS can accommodate small sample size, Ringle, Wende and Will, (2005).

\section{Results and Discussion}

\subsection{Demographic Profile of Respondents}

The table 1 shows the profile of respondents, the result reveals that $76.2 \%$ of the respondents have less than 5 years of existence; this implied that majority of the respondents are not long in the operations. In terms of ownership structures $81.5 \%$ of respondents are individual owner, while $9.7 \%$ are partnership business. With regards to no. of employees $85.1 \%$ have less than 20 employees; this indicates the uniqueness of one man business. Furthermore, most of the Manufacturing industry have less than 1 million, Nigerian currencies as their Assets and represent 46. \%.( see table 1).

Table 1. Demographic breakdown of respondents

\begin{tabular}{|c|c|c|c|}
\hline Demographic profile & Category & No. Of respondents & $\%$ \\
\hline \multirow{3}{*}{ Years of existences } & Less 5 years & 189 & 76.2 \\
& $5-10$ years & 34 & 13.7 \\
& $11-20$ years & 17 & 6.9 \\
& $21-40$ years & 8 & 3.2 \\
\hline \multirow{2}{*}{ Location } & Kano & 233 & 94 \\
& Lagos & 15 & 6 \\
\hline Ownership & Individual & 202 & 81.5 \\
\hline
\end{tabular}




\begin{tabular}{|c|c|c|c|}
\hline & Partnership & 24 & 9.7 \\
& Joint venture & 3 & 1.2 \\
& Others & 19 & 7.7 \\
\hline \multirow{4}{*}{ No. Of employees } & Less 20 & 211 & 85.1 \\
& $21-40$ & 17 & 6.9 \\
& $41-60$ & 11 & 4.4 \\
& $61-80$ & 1 & 0.4 \\
& $81 \&$ above & 8 & 3.2 \\
\hline \multirow{5}{*}{ Activities } & Food \& beverages & 100 & 40.3 \\
& Tobacco & 42 & 16.9 \\
& Textiles & 19 & 7.7 \\
& Weaving \& dressing & 61 & 24.6 \\
& Leather \&handbags & 17 & 6.9 \\
& Non-metric & 1 & 0.4 \\
& recycling & 3 & 2.8 \\
& others & 1 & 0.4 \\
\hline \multirow{5}{*}{ Assets } & Less 1million & 114 & 46 \\
& $1-100 \mathrm{~m}$ & 77 & 31 \\
& $101-200 \mathrm{~m}$ & 50 & 20.2 \\
& $201-300 \mathrm{~m}$ & 3 & 1.2 \\
& $301 \&$ above & 4 & 1.6 \\
\hline
\end{tabular}

\subsection{Goodness of Measures}

The paper assessed the construct reliability by calculating a composite reliability (CR) for each construct after maximum likelihood estimation was employed. The advices of Fornell and Larker (1981) were taken into consideration when calculating the CR index along side with reliability calculation as illustrated in Table 2. Consequently, the average variance extracted (AVE) were assessed for each construct (Anderson, 1982; Bagozzi \& Lynn, 1982; Fornell \& Larcker, 1981; Hair, Anderson, Tatham \& Black, 1998). AVE was used to gauge convergent validity (Fornell \& Larcker, 1981; Hair et al., 1998; Ping, 2004) suggested convergent measures should contain less than $50 \%$ error variances meaning that AVE should be 0.5 or above. The paper used cut-off value of 0.70 and 0.50 for CR and AVE respectively (Bagozzi \& Yi, 1998; Hair et al., 1998; Hair et al., 2010). The scale of reliability range from 0.89 to 0.93 , and the factor loadings ranged from 0.59 to 0.94 ( $p<0.05$ ), and the AVE ranged from 0.61 to 0.82 which is above criteria (Fornell \& Larcker, 1981; Hair et al., 1998; Ping, 2004). See table 2 bellow:

Table 2. Result of CFA for Measurement Model

\begin{tabular}{|c|c|c|c|c|c|}
\hline Construct & Items & $\begin{array}{c}\text { Internal reliability } \\
\text { Cronbach alpha }\end{array}$ & $\begin{array}{l}\text { Factor Cross } \\
\text { loading }\end{array}$ & $\begin{array}{l}\text { Composite } \\
\text { Reliability }\end{array}$ & $\begin{array}{c}\text { Average variance } \\
\text { extracted }\end{array}$ \\
\hline $\begin{array}{l}\text { Corporate } \\
\text { Reputation }\end{array}$ & $\begin{array}{l}\text { RT } 03 \\
\text { RT } 04 \\
\text { RT } 05\end{array}$ & 0.8922266 & $\begin{array}{l}0.913514 \\
0.948030 \\
0.859419\end{array}$ & 0.933416 & 0.823957 \\
\hline $\begin{array}{l}\text { Organizational } \\
\text { performance }\end{array}$ & $\begin{array}{l}\text { OP } 01 \\
\text { OP } 05 \\
\text { OP } 06 \\
\text { OP } 07\end{array}$ & 0.831460 & $\begin{array}{l}0.589451 \\
0.923204 \\
0.945814 \\
0.787970\end{array}$ & 0.891343 & 0.678805 \\
\hline $\begin{array}{c}\text { BSR } \\
\text { Commitment }\end{array}$ & $\begin{array}{l}\text { OCO2 } \\
\text { OCO3 } \\
\text { OC04 }\end{array}$ & 0.872485 & $\begin{array}{l}0.828303 \\
0.747999 \\
0.863753\end{array}$ & 0.933416 & 0.823957 \\
\hline
\end{tabular}




\begin{tabular}{|l|l|l|l|l|l|}
\hline & OC05 & & 0.904016 & & \\
& OC06 & & 0.711391 & & \\
OC07 & & 0.597378 & & \\
\hline
\end{tabular}

Considering, the reliability analysis, we established discriminant validity by calculating share variance between each pair of constructs and verifying that it was lower than the average variance extracted from the individual construct (Bagozzi \& Lynn, 1982; Fornell \& Larcker, 1981). As shown in Table 3, the squared correlations for each construct are less than the square root of average variance extracted by the indicators measuring that construct indicating adequate discriminant validity. In general, the measurement model demonstrated adequate reliability, convergent validity, and discriminant validity.

Table 3. Discriminant validity of construct

\begin{tabular}{|l|c|c|c|}
\hline & Reputation (1) & Commitment to BSR (2) & Performance (3) \\
\hline Reputation (1) & $\mathbf{0 . 9 0 7 7 2}$ & & \\
\hline Commitment to BSR (2) & 0.186374 & $\mathbf{0 . 7 8 5 8 5 1}$ & \\
\hline Performance (3) & 0.315168 & 0.138162 & $\mathbf{0 . 8 2 3 8 9 6}$ \\
\hline
\end{tabular}

\subsection{Hypotheses Testing}

Table 5. Model Hypotheses

\begin{tabular}{|c|c|c|c|c|}
\hline Hypotheses & Path coeficient & S.E & T. Value & Decision \\
\hline PF<--- RT & 0.300 & 0.09913 & 3.025 & Supported \\
\hline PF <--- OC & 0.082 & 0.12246 & 0.672 & Not Supported \\
\hline
\end{tabular}

This study examines the relationship between BSR commitments, corporate reputation on organizational performance in Nigerian manufacturing industry. The interpretation of the hypotheses results is summarized in table 5 above. The result reveals that there is a significant relation between corporate reputation and organizational performance (Path coefficient $=0.300$; $t=3.025$ ). This finding is in line with the study of Hsu (2012), Rettab et al., (2009). Hence, H1 is supported. Similarly, the relationship between BSR commitment and organizational performance found insignificant relation (Path efficient $=0.082$ ) and result is not in line with (Ahmad et al., 2011 \& Rettab et al., 2009), thus H2 not supported.

\section{Conclusion, Managerial, Theoretical Contribution \& Direction for Future Studies}

In this study the paper examines the relationships between BSR dimension and organizational performance in emerging nation particularly Nigeria. The results are fairly, BSR has a significant and positive relation with corporate reputation and organizational performance. This result is in line with previous empirical studies conducted in western developed nations showing a positive relation BSR efforts and organizational performances, surprisingly, BSR commitment not significant relation with organizational performance in manufacturing industry in Nigeria. Further, this study reveals the impact of BSR on organizational performance in emerging nation like Nigeria which is similar to that of developed nation, e.g. USA \& Western Europe. Equally this study has extended the current body of knowledge beyond developed nations.

However, scholars and practitioners in developed nation have a numerous of evidence on the relationship between BSR and organizational performance, to the best of our knowledge this study provides an evidence of this relationship in a non- developed nation context. Similarly, this result raise doubts about the validity of the assertion that, as a result of the absence of strong institutional support for BSR, and presence of weak and in effectual laws to guard against unethical practices (Fo0, 2007). 


\subsection{Theoretical Contribution}

Businesses are progressively in front of pressure to function in socially responsible ways (Mohr et al., 2001). The significant of BSR for firms should be due its relations with financial outcomes or actions outcomes of stakeholders. Thus, BSR can be viewed and used as a firm's differentiation strategy, a form of strategic investment comparable to awareness (McWilliams, et al., 2006). This study examines the relationship between BSR commitment and Corporate Reputation on organizational performance. The results indicate that perception concerning BSR initiatives of Manufacturing industry have a positive effect on Corporate reputation but not significant effect on BSR commitment of manufacturing industry in Nigeria.

\subsection{Managerial Contribution}

The findings of this study have the following managerial for manufacturing industry. First, the fact, that BSR activities improve corporate reputation of manufacturing industry, encourages managers of manufacturing industry to continue investing in BSR actions. Stakeholder tend to be more satisfied with business that are more socially responsible, perceived these business more favourable in terms of corporate reputation, and reward these business. Secondly, managers should employ BSR activities to build corporate reputation without any other purpose when designing corporate reputation. This implication is in line with business ethics from a Kantian perspective (Bowie, 1999), and explains why BSR initiatives may be viewed as real options (Husted, 2005). BSR actions act as safety net to buffer and protect business from unpredictable negative events (Fombrun, et al., 2000). For the role of real option or policy maker in manufacturing industries that BSR actions are key elements that lead to intangible assets that BSR accrues, such as corporate reputation, commitment, and legitimacy.

\subsection{Limitations \& Direction of future studies}

As with any research, these study some limitations that should be noted. First, the data for the study were mainly collected from selected manufacturing industry in Kano metropolis, Nigeria. Thus, this is based on data from a single country and caution must be taken when generalizing the results of this study to other developing nation. Second, the direct effects of the independent variables on the dependent variables are difficult to conclude. In order to overcome some of these limitations, future studies of increasing the sample sizes and examines other industries or across different industries. In addition, future studies should employ a longitudinal research design, so that the direct effect of the independent variables on the dependent variables could be concluded.

\section{Reference}

Aguilera, R., Ruth, V., Rupp, D., Williams, C., \& Ganapathi, J. (2007). Putting the S Back in Corporate Social Responsibility: A Multilevel Theory of Social Change in Organizations, Academy of Management Review, 32, 836863.

Ahmad, N. H., \& Ramayah, T. (2012), Does the notion of 'Doing Well by Doing Good' Prevail Among Entrepreneurial Ventures in Developing Nation?. Journal of Business Ethics, 106, 479-490.

Ahmad, K. Z., Veerapandian, K.,\& Ghee. W. (2011). Person - Environment Fit: The missing Link in the Organizational Culture - Commitment Relationship, International Journal of Business and Management, 6(11),11-20.

Allen, N.J., \& Meyer, J.P. (1990). The Measurement and Antecedents of Affective, Commitment and Normative Commitment to the Organization. Journal of Occupational Psychology, 63, 1-18.

Ambrose, M. L., Arnaud, A., \& Schminke, M. (2008). Individual Moral Development and Ethical Climate: The influence of Person-Organization Fit on Job Attitudes. Journal of Business Ethics, 77, 323-333. 
Amaeshi, K., Adi, B., Ogbechie, C. \& Amao, O. (2006). Corporate Social Responsibility in Nigeria: Western Mimicry or Indigenous influence? No 39-2006, ICCSR Research paper series-ISSN 1479-5124, The University Nottingham.

Bagozzi, R. P. \& Lynn, P. W. (1982). Representing and Testing Organizational Theories: A Holistic Construal, Administrative Science Quarterly 27, 459-489. Bagozzi, R. P., \& Yi, Y. (1988). On the Evaluation of Structural Equation Models, Journal of the Academy of Marketing Science, 16, 74-94.

Basu, K., \& Palazzo, G. (2008). Corporate social responsibility: A process model of sense making. Academy of Management Review, 33(1), 122-136.

Bentler, P. M. (1990), Comparative Fit Indexes in Structural Equation Modelling, Psychological Bulletin 107, 238-246.

Berman, S. L., Wicks, A. C., Kotha, S., \& Jones, T. M. (1999). Does stakeholder orientation matter? The relationship between stakeholder management models and firm financial

Bhattacharya, C. B., \& Sen, S. (2004). Doing better at doing good: When, why, and how consumers respond to social initiatives. California Management Review, 47(1), 9-24.

Bollen, K. A. (1989). Structural equations with latent variables. New York: Wiley.

Bowie, N. E. (1999). Business ethics: A Kantian perspective. Oxford: Blackwell.

Brammer, S., \& Millington, A. (2005). Corporate reputation and philanthropy: An empirical analysis. Journal of Business Ethics, 61, 29-44.

Byrne, B. M. (2001). Structural equation modeling with AMOS: Basic concepts, applications, and programming. Mahwah, $\mathrm{NJ}$ : Lawrence Erlbaum Associates, Inc.

Cameron, K. (1986a). A study of organizational effectiveness and its predictors. Management Science, 32(1), 87-112.

Chau, P. Y. K., \& Hu, P. J. H. (2001). Information technology acceptance by individual professionals: A Model comparison approach. Decision Sciences, 32(4), 699-719.

Chew, J., \& Chan, C. C. A. (2006). Human resource practices, organizational commitment and intention to stay. International Journal of Manpower, 29(6), 503-522.

Cochran, P. L., \& Wood, R. A. (1984). Corporate social responsibility and financial performance. Academy of Management Journal, 27(1), 42-56.

Deephouse, D. (2000). Media Reputation as a Strategic Resource: An Integration of Mass Communication and Resource-Based Theories, Journal of Management 26, 1091-1112.

Dodds, W. B., Monroe, K. B., \& Grewal, D. (1991). The effects of price, brand and store information on buyers' product evaluations. Journal of Marketing Research, 28(4), 307-319.

Egri, P. C., \& Ralston, D. A. (2008). Corporate Responsibility: A review of International Management Research From 1998 to 2007. Journal of International Management, 14(4), 319-339.

Fombrun, C. J., Gardberg A. N., \& Sever, M. J. (2000). The Reputation Quotient: A Multi-Stakeholder Measure of Corporate Reputation, The Journal of Brand Management, 7, 241-255.

Fombrun, C. \& Shanley, M. (1990). What's in a Name? Reputation Building and Corporate Strategy, Academy of Management Journal, 33, 233-258.

Foo, L. M. (2007). Stakeholder Engagement in Emerging Economies: Considering the Strategic Benefits of Stakeholder Management in a Cross-Cultural and Geopolitical Context, Corporate Governance, 7, 379-387.

Fornell, C., \& Larcker, G. D. (1981). Evaluating Structural Equation Models with Unobservable Variables and Measurement Errors, JMR, Journal of Marketing Research, 18, 39-50.

Freeman, R. E. (1984). Strategic management: A stakeholder perspective. Englewood Cliffs, NJ: Prentice Hall.

Frynas, J. (2005). The False Developmental Promise of Corporate Social Responsibility: Evidence from Multinational Oil Companies, International Affairs, 81, 581-598.

Graves, S. \& Waddock. S. (1994). Institutional Owners and Corporate Social Performance, Academy of Management Journal, 37, 1034-1046.

Griffin, J. \& Mahon, J. (1997). The Corporate Social Performance and Corporate Financial Performance Debate: Twentyfive Years of Incomparable Research, Business \& Society, 36, 5-31.

Hair, J. F., Jr., Black, W. C., Babin, B. J., Andersen, R. E., \& Tatham, R. L.(2010). Multivariate data analysis (7th ed.). Upper Saddle River, NJ: Pearson Prentice Hall.

Hair, J. F., Anderson, E. R., Tathamand, L. R., \& Black, C. W. (1998). Multivariate Data Analysis, 5th (ed.), Prentice Hall, Upper Saddle River, NJ.

Hillman, A. J., \& Kein, G. D. (2001). Shareholder value, Stakeholder management and social issues: what is the button line? Strategic Management Journal, 22(2), 125. 
Hsu. K. (2012). The Advertising Effects of Corporate Social Responsibility on Corporate Reputation and Brand Equity: Evidence from the Life Insurance Industry in Taiwan. Journal of Business Ethics. 109: 189-201.

Hu, L. T., \& Bentler, P. M. (1998). Fit indices in covariance structure modeling: Sensitivity to under parameterized model misspecification. Psychological Methods, 3, 424-453.

Hu, L. \& Bentler, M. P. (1999). Cutoff Criteria for Fit Indexes in Covariance Structure Analysis: Conventional Criteria Versus New Alternatives, Structural Equation Modeling, 6, 1-55.

Hung, M. P., Cheng, B. S., \& Chou, L. F. (2005).Fitting in organizational values. The mediating role of personorganization fit between CEO charismatic leadership and employee outcomes. International Journal of Manpower, 26(1), 35-110.

Husted, B. \& Salazar, J. (2006). Taking Friedman Seriously: Maximizing Profits and Social Performance, Journal of Management Studies, 43, 75-91.

Husted, B. W. (2005). Risk Management, real options and corporate social responsibility. Journal of Business Ethics, 60(2), 175-183.

Jaworski, B. \& Kohli, A. (1993). Market Orientation: Antecedents and Consequences, Journal of Marketing, 57, 53-70.

Kaplan, R. S., \& Norton, D. P. (1992), The Balanced Scorecard - Measures That Drive Performance, Harvard Business Review, 70 (1), 71-79.

Lai, C. S., Chiu, C. J., Yang, C. F., \& Pai, D. C. (2010). The effects of corporate social responsibility on brand performance: The mediating effect of industrial brand equity and corporate reputation. Journal of Business Ethics, 95(3), 457-469.

Lange, D., Lee, P. M., \& Dai, Y. (2011). Organizational reputation: An overview. Journal of Management, 37(1), 153-184.

Lee, M. P. (2008). A review of the theories of corporate social responsibility: its evolutionary path and the road ahead. International journal of management reviews.10 (1), 53-73.

Lok, P., and Crawford, J. (2001), 'Antecedents of Organizational Commitment and the Mediating Role of Job Satisfaction,' Journal of Managerial Psychology, 16(8), 594-613.

Maignan, I., Ferrell, O. C., \& Ferrell, L. (2005). A stakeholder model for implementing social responsibility in marketing. European Journal of Marketing, 39(9/10), 956-977.

McGuire, J. B., Sundgren, A., \& Schneeweis, T. (1988). Corporate Social Responsibility and Firm Financial Performance, Academy of Management Journal, 31, 854-872.

McWilliams, A., Siegel, D., \&. Wright. M. (2006).Corporate Social Responsibility: Strategic Implications, Journal of Management Studies, 43, 1-18.

Miller, D. \& Lee, J. (1999). People matter: commitment to employees, strategy and performance in Korean firms, Strategic Management Journal, 20, 579-93.

Mowday, R.T., Steers, R.M. \& Porter, L.W. (1982). Employees, Organization Linkages, Academic Press, New York, NY.

Mohr, L. A., Webb, D. J., \& Harris, K. E. (2001). Do consumers expect companies to be socially responsible? The impact of corporate social responsibility on buying behavior. Journal of Consumer Affairs, 35(1), 45-72.

Morris, M. H., Schindehutte, M., Walton, J., \& Allen, J. (2002). The ethical context of entrepreneurship: Proposing and testing a developmental framework. Journal of Business Ethics, 40(4),331-361.

Okoye, A. (2009). Theorising corporate social responsibility as an essentially contested concept: is a definition necessary? Journal of Business Ethics, 89 (4), 613-627.

Pedersen, E., \& Huniche, M. (2006). Corporate Citizenship in Developing Countries Copenhagen Business School Press, Copenhagen.

Peloza, J. \& Papania, L. (2008). The Missing link Between Corporate Social Responsibility and Financial Performances: Stakeholder Salience and Identification, Corporate Reputation Review, 11(20), 169-181.

Petrick, J. F. (2002). Development of a multi-dimensional scale for measuring the perceived value of a service. Journal of Leisure Research, 34(2), 119-134.

Ping, R. A. (2004). On Assuring Valid Measures for Theoretical Models Using Survey Data, Journal of Business Research, 57, 125-141.

Porter, M., \& Kramer, M. (2006). Strategy and society: The link between competitive advantage and corporate social responsibility. Harvard Business Review, 84(12), 78-92.

Porter, L.W., Steers, R.M., Mowday, R.T., \& Boulian, P.V. (1974). Organizational Commitment, Job Satisfaction, and Turnover among Psychiatric Technicians. Journal of Applied Psychology, 59, 603-609.

Rangriz, H., Mehrabi, J. (2010). The relationship between emotional intelligence, organizational commitment and employee's performances in Iran. International Journal of Business and Management, 5(8), 50-56. 
Rashid, M. Z. A., Sambasivan, M., \& Johari, J. (2003). The influence of corporate culture and organizational commitment on performance. Journal of Management Development, 22(8), 708-728.

Rettab, B., Brik, A. B., \& Mellahi, K. (2009). A study of management perception of the impact of corporate social responsibility on organizational performance in emerging economics: The case of Dubai. Journal of Business Ethics, 89, 371-390.

Ringle, C. M., Wende, S., \& Will, A. (2005). SmartPLS 2.0 (M3) beta, Hamburg: http://www.smartpls.de.

Roberts, P., \& Dowling. G. (2002) Corporate Reputation and Sustained Superior Financial Performance, Strategic Management Journal, 23, 1077-1093.

Sani, B.M., \& Sulaiman, S. (n.d.). The Structure of Kano Economy. Retrieved from http://www.kanoonline.com/

Shamsie, J. (2003). The Context of Dominance: An Industry-Driven Framework for Exploiting Reputation, Strategic Management Journal, 24, 199-216.

Siltaoja, M. E. (2006). Value priorities as combining core factors between CSR and reputation-a qualitative study. Journal of Business Ethics, 68(1), 91-111.

Smith N. C. (2003). Corporate social responsibility: whether or how? California Management Review 45(4): 52-76.

Steers, R.M. (1977). Antecedents and outcomes of organizational commitment, Administrative Science Quarterly, 22, 4656.

Vance, S. C. (1975). Are Socially Responsible Corporations Good Investment Risks?, Management Review, 64, 19-24.

Venkatraman, N., \& Ramanujam, V. (1986). Measurement of business performance in strategy research: a comparison of approaches. Academy of Management Review, 1, 801-814.

Verschoor, C.C. (1998). A Study of the link between a corporations financial performances and its commitment to ethics, Journal of Business Ethics, 17, 1509-1516.

Waddock, S., \& Graves, S. (1997). The Corporate Social Performance-Financial Performance Link, Strategic Management Journal, 18, 303-319.

Whitley, R. (1992). Business Systems in East Asia: Firms, Markets, and Societies (Sage, London, Newbury Park).

Wright, P., \& Ferris, S. (1997). Agency Conflict and Corporate Strategy: The Effect of Divestment on Corporate Value, Strategic Management Journal, 18, 77- 83.

Yamane, T. (1967). Statistics: An Introductory Analysis, $2^{\text {nd }}$ Ed., New York: Harper and Row. 
